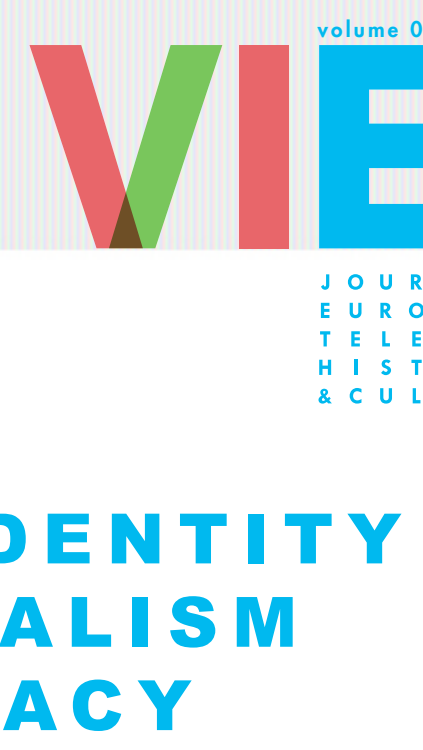

\title{
FROM EUROPEAN IDENTITY AND MEDIA IMPERIALISM TO PUBLIC DIPLOMACY
}

\section{THE CHANGING RATIONALE BEHIND EURONEWS}

\author{
Eva Polonska-Kimunguyi \\ Monash European and EU Centre \\ Monash University \\ Room H5.108, Building $\mathrm{H}$ \\ 900 Dandenong Rd \\ Caulfield East, VIC 3145, Melbourne \\ Australia \\ eva.polonska@monash.edu \\ Patrick Kimunguyi \\ Monash European and EU Centre \\ Monash University \\ Room H5.108, Building H \\ 900 Dandenong $\mathrm{Rd}$ \\ Caulfield East, VIC 3145, Melbourne \\ Australia \\ patrick.kimunguyi@monash.edu
}

\begin{abstract}
Euronews can be regarded as Europe's most experimental and successful pan-national broadcaster. It is increasingly international in its organisation and output. The issues covered no longer concentrate on Europe. 'Going global' is the channel's new motto.

This paper outlines the changing rationale behind the creation of Euronews. It starts by discussing the American cultural imperialism of the 1970s and 1980s and the way it ignited European responses and counter-measures. It subsequently examines the politics of pan-national identity building in Europe and media's role in the process. Finally, it demonstrates how Euronews has transformed itself into an instrument of the European Union's transnational public diplomacy.
\end{abstract}

Keywords: Euronews, international broadcasting, public diplomacy 


\section{Introduction}

Euronews has perhaps been Europe's most succesfull pan-national broadcaster to date. Created in the early 1990 s to be a new voice in the American-dominated at the time global information sphere, it was also envisaged to take part in the creation of a common European identity and to generate support for the integration project. ${ }^{1}$ Despite frequent criticisms from its rivals and academia, the broadcaster has managed to build a significant audience throughout the continent and beyond. With its subscribers outnumbering those of BBC and CNN combined, Euronews continues to expand into new markets. ${ }^{2}$ Started by a handful of European public broacasters, it has become increasingly international in its ownership and news-making output, with twenty one current stakeholders in the Ural Mounains, Northern Africa and the Middle East.

Yet international broadcasting has recently undergone a crisis of purpose (Price, 2003). Since the end of the Cold War, even including the period after 9/11, just what drives international media has been hard to define. The aims of international broadcasting vary, from the provision of journalistic information, promotion of a sponsor's image and interests, financial profits, political or religious propaganda and campaigning, to attempts to shape the opinion of people and leaders in other countries. ${ }^{3}$ Several developments - globalization, the communication revolution and the growing participation of the mass public in politics worldwide - have affected how states communicate themselves to their domestic and foreign audiences. Today, it is no longer possible for an open practice of foreign broadcasting policy, as was commonplace during the Cold War. Having an acceptable product alone is not enough to ensure reaching a substantial audience. International audiences mostly rely on reports from journalists with whom they share language, politics, and culture. ${ }^{4}$ Whether the results are worth the effort varies significantly from case to case. ${ }^{5}$

This article focuses on the present identity and strategy of Euronews, Europe's multilingual, pan-national broadcaster. It outlines the changing rationale behind the creation of the channel. Firstly, it examines the politics of pan-national identity-building in Europe and the media's role therein. Secondly, it looks at American cultural imperialism of the 1970 s and 1980s and the way this ignited the European response and subsequent counter-measures. It positions Euronews amongst the two debates on identity, as well as its role in countering the American media hegemony. On the basis of the editorial policies and self-assessment of the channel's editors and journalists, ${ }^{6}$ the article argues that at present, Euronews oscillates somewhere between the national and transnational (European) spheres, but officially trying to avoid both. Thus, its contribution to pan-national identity building may not be substantial.

The article will argue that the broadcaster's transnational, or European perspective can only be found in the selection of topics for its news programs. Different reporting styles and professional values amongst the journalists from the channel's multiple language sections reflect the values that can be found in Europe's various national journalistic cutures. As "identity remains the prisoner of language,"7 it is mostly the variety of languages and national journalistic practices that enforce the stylistic and interest-oriented national focus of news.

${ }^{1}$ Interview with Sergio Cantone, Managing Editor of Euronews, Brussels Office, July 2011

2 “Euronews Pure", Euronews Media Pack, available at: http://www.euronews.com/media/download/mediapack/euronews mediapack en 2011.pdf

${ }^{3}$ The best known and the oldest examples are semi-autonomous, state-sponsored international broadcasters are Voice of America (VoA), Radio Free Europe, BBC World Service and Deutsche Welle operating since WWII. Most recent players include CNN and Al-Jazeera, that, altough widely considered as conveyors of the American and Arabic case respectively, do not (at least officially) live off the government funding. Both broadcasters operate within the spheres of journalism and financial profit and, at the same time, within the confines of their host country's policies. See: Ajami, F. What the Muslim World is Watching, New York Time Magazine, Nov 18, 2001; Gilboa, E. (2008), "Searching for a Theory of Public Diplomacy", The ANNALS of the American Academy of Political and Social Science, vol. 616 no.1; Price, M., "Public Diplomacy and the Transformation of International Broadcasting"; Cardozo Arts and Entertainment Law Journal, Vol. 21, 2003

${ }^{4}$ Philip Seib, "Transnational Journalism, Public Diplomacy and Virtual States"; Journalism Studies, Routledge, vol. 11, no. 5, 2010

${ }^{5}$ Philip Seib, The Al Jazeera Effect, Dulles, VA: Potomac, 2008

${ }^{6}$ Semi-structured interviews were conducted in July 2011 with journalists from the broadcaster's newly opened office in Brussels. Altogether five journalists and the editor in chief were interviewed.

${ }^{7}$ Michael Bruter, 'On What Citizens Mean by Feeling 'European: Perceptions of News, Symbols and Borderless-Ness'; Journal of Ethnic and Migration Studies, 30(1) 2003, p. 23 
E. Polonska-Kimunguyi and P. Kimunguyi, From European Identity and Media Imperialism to Public Diplomacy

The article concludes that more recently, there has been yet another turn in the broadcaster's strategy. By accepting funding from the European Union, as well as by embracing non-European languages to target non-European audiences, Euronews has transformed itself from a public service-type broadcaster with an internal focus to an instrument of the EU's transnational public diplomacy.

\section{European Identity and the Media}

Grasping the essence of 'European' identity is not an easy task. Attempts to determine a common European self distinguishable from that of other cultures started as early as the late 1940s. Efforts to define common European identity focussed on shared features of Christianity, morality, political tradition of the rule of law and self-government, and a common symbolic intellectual culture, particularly as developed in the field of science by the Western European nations. ${ }^{8}$ Smith (1991) described European culture as "the heritage of Roman law, Judeo-Christian ethics, Renaissance humanism and individualism, Enlightenment rationalism and science, artistic classicism and romanticism and above all traditions of civil rights and democracy... [that] have created a common European cultural heritage." ${ }^{\prime}$ This definition, however, excludes the influence of large-scale migration and the increasingly heterogeneous populations of the EU Member States.

The EU Commission concluded in the early 1990s that the values which "could form the basis of a European identity" were "the rejection of war, the fight against poverty and unemployment, protection of the environment; Human Rights, freedom and democracy; the wealth and diversity of European culture." ${ }^{10}$ It could seem, though, that other liberal democracies would easily fall into this category.

The potential of media industries to promote a common identity was pointed out by the European Commission in the mid-1980s. The Solemn Declaration on European Identity of 1983 invited Member States to "promote European awareness and to undertake joint action in various cultural areas", particularly information, education, audio-visual policy and the arts. The Commission interpreted it as permission to pursue cultural initiatives, not for their own sake but "in order to affirm the awareness of a common cultural heritage as an element in the European identity." ${ }^{11}$ The emphasis on consciousness-raising as a strategy for bringing Europe closer to the citizens and 'creating Europeans' signalled a new departure in the European Commission's approach to the neglected domain of culture.

A visible Peoples' Europe period followed throughout the $1980 \mathrm{~s} .{ }^{12}$ Information and the idea of pan-national television were singled out as two key agents of European consciousness-building. ${ }^{13}$ The Maastricht Treaty considerably enlarged the EU's sphere of governance. It included provisions on European citizenship ${ }^{14}$ and assigned new areas like culture, education, youth, consumer protection and public health under the jurisdiction of the EU. As European identity was not "engrained in people's minds" 15 , new information policy was launched after Maastricht as a tool to

${ }^{8}$ Richard Collins, From satellite to single market: new communication technology and European Public Service television, London; New York: Routledge, 1998

${ }_{9}^{9}$ Anthony Smith, National Identity, Harmondsworth: Penguin, 1991, p. 174

${ }^{10}$ European Commission 'Reflection on Information and Communication Policy of the European Community', Report of the Group of Experts chaired by Willy De Clerq, Member of the European Parliament, RP 1051 93, 1993, p. 2

${ }^{11}$ cited in De Witte, B. 'Building Europe's Image and Identity', in: A. Riijksbaron, W. Roobol and M. Weisglas (eds.) Europe from a Cultural

Perspective, The Hague: UPR: 121-31, 1987, p. 36

${ }^{12}$ Chris Shore, Building Europe; the Cultural Politics of European Integration, Routledge, 2000

${ }^{13}$ European Commission, 'Television without Frontiers: Green Paper on the Establishment of the Common Market for Broadcasting especially for Satellite and Cable', COM (84) final, Luxembourg; OOPEC, 1984

${ }^{14} \mathrm{EU}$ citizenship established free movement and residence within the Community, rights to vote in EU Parliamentary elections and local election in the county of residence, diplomatic protection abroad for all Europeans, non-judicial means of redress (petitions to EU Parliament and complaints to the EU Ombudsman). All the rights were not offered to non-EU nationals, and the citizens of EU Member States were already enjoying them on the basis of their national citizenship.

${ }^{15}$ Willy De Clerq, W. (1993) Reflection on Information and Communication Policy of the European Community, Report by the Group of Experts, Commission of the European Communities, 1993, p. 2 
build both 'Europe' and the 'Europeans'. New media laws and the creation of pan-European media organisations were also proposed. The founders of the European Community quickly realised, however, that although co-operation in the economic domain may bring visible results in form of prosperity and wealth, the cultural barriers would not disappear so easily. ${ }^{16}$

\section{3 'Cultural Imperialism' and the European Counter- measures}

The search for a common 'European soul' was to a degree propelled by the international media landscape in the 1970s and 1980s. 'Cultural Imperialism'17 became a widely discussed phenomenon on the international arena, when Herbert Schiller published his book Mass Communication and the American Empire in 1969. The American domination of media was noted worldwide. According to Schiller, it was Herbert Hoover, the president of the Board of Trade in 1920s, who first saw the potential of the media to establish and then maintain American dominance in the world. Hollywood became a promoter of US consumer goods and the 'American way of life'. The media's advertising potential was also noted by Henry Luce, the founder of Time magazine. In his book The American Century, written in 1941, Luce argued that the "USA's potential to influence, if not control, imagery and opinion overseas was, in fact, the new quintessence of power." ${ }^{18}$ American domination of the rest of the world through the use of media became an enduring feature of the twentieth century. ${ }^{19}$

The study of the international flow of information throughout the 1970s revealed that Western Europe was also significantly represented - albeit in a more minor way - among the program exporters to the developing world. ${ }^{20}$ Two of the four biggest news companies, Agence France-Presse (AFP) and Reuters, were French and British respectively. This emphasized that media organizations in Europe were also involved in an essentially imperialist project, in that they saw themselves sending their message to the world and conquering other nations' minds through vision and sound. ${ }^{21}$

In the following decades, the global flow of information and unequal technological development between the most and the least advanced countries dominated the international debates on media and its regulation. At the UNESCO

\footnotetext{
${ }^{16}$ Jérôme Bourdon, 'Unhappy Engineers of the European Soul: the EBU and the Woes of Pan-European Television', International Communication Gazette, 69, 2007; 264

${ }^{17}$ The 'Cultural Imperialism' thesis rested on several assumptions: 1) that global media promoted the dependency of states on the West rather than promoting their economic growth, 2) that the imbalance in media content flow undermined cultural autonomy of importing countries or held back their development, 3 ) that this imbalance gave rise to cultural homogenization and increased the relative power of large and wealthy producers while hindering the development of national identities; See: McQuail, D. (2000) Mass Communication Theory, London: Sage

${ }^{18}$ Cited in David Morley 'Globalisation and cultural imperialism reconsidered: old questions and new guises' in: James Curran and David Morley (eds.) Media and Cultural Theory, New York: Routledge, 2006, 32

${ }^{19}$ Throughout the 1970s, two Finnish scholars Nordenstreng and Varis conducted their research on the flow of television programs in the world. From the responses received from 50 countries they found out that the informational flow of television programs was nearly entirely one way: from the United States to the rest of the world. Western Europe was also significantly represented - albeit in a more minor way - among the program exporters. Nordenstreng and Varis concluded that majority of those programs were entertainment, and that the one-way flow was due to historical conditions related to the development of television, economic conditions and demographic characteristics of the receiving countries. The poorest countries were the most dependent on foreign programming. The richest, like the US, with their own resources, and where cinema and television developed early, were the biggest exporters: See Kaarle Nordenstreng, and Tapio Varis, Television Traffic - A One-Way Street? A Survey and Analysis of the International Flow of Television Program Material; Paris: UNESCO Reports and Papers on Mass Communication, No. 70,1974 ${ }^{20}$ Nordernstreng and Varis, 1974

${ }^{21}$ Anthony Giffard, UNESCO and the media; New York: Longman, 1989; Leonard Marks, 'New World Information Order: A Bad Idea that Refuses to Die' in: Leonard Marks (ed.) The Media Crisis, Miami: World Press Freedom Committee, 1981; Kaarle Nordenstreng, The Mass Media Declaration of UNESCO, Norwood, NJ: Ablex, 1984
} 
conference in 1970, developing nations, ${ }^{22}$ under India's leadership, officially called for a more balanced and regulated flow of information, and proposed to prepare a declaration on the "fundamental principles governing the use of mass media". ${ }^{23}$ This was in sharp opposition to the arguments from the US and Western Europe, who maintained that state control of mass media was in conflict with the free flow of information. ${ }^{24}$

Countries unaligned with UNESCO also expressed concerns about the imbalance of the global flow of information and the need for its limitation. A meeting of heads of states in Algiers in September 1973 adopted an Action Program for Economic Cooperation ${ }^{25}$ advising members to "reorganise existing communications channels which are the legacy of the colonial past, and which have hampered free, direct and fast communication among them" ${ }^{26}$ For newly independent states, the emancipation and development of their national media was an integral part of the overall struggle for political, economic and social independence. ${ }^{27}$

On a domestic front back in Europe, technological development in the 1970s allowed Western European states to have a small number of national TV channels that produced enough programs to satisfy their citizens' needs, as well as to exercise some influence abroad. That situation changed, however, throughout the 1980s. With the arrival of new communication platforms, such as sattellite and cable television, heralding unprecedented opportunities to operate hundreds of channels, Western European television, dominated by the public service model, failed to provide the variety, entertainment, or even the quantity of programs their audiences required. Hollywood was more than happy to fill the gap. As a result, the Western European media increasingly found themselves, if not eliminated from the international communication flow, then at least compromised and sidelined. ${ }^{28}$ This goes a long way to explaining their recourse to the language of free international trade. European states, having lost their earlier 'imperialist' influence throughout the 1980s, and now feeling more 'threatened' than ever by American media expansion, joined the chorus of the developing world in expressing concerns about its own culture and identity. ${ }^{29}$

\section{Hence Europe's Own International Broadcasting}

To create the sought after pan-national identity and to counter cultural imperialism, Europe embarked on an ambitious plan largely based on the involvement of media industries. The People's Europe innitiative, launched in the 1980s, placed media at the heart of making 'Europeans' and making the European message heard on the continent. The "Television without Frontiers" Directive of 1989 employed television as key in the process of European

\footnotetext{
${ }^{22}$ The Soviet Union quickly joined the developing world in accusing Western states of 'media imperialism', and of serving the interests of their news and entertainment corporations in search for markets outside their own territories. The emerging, probably unintentional, alliance of developing countries and the Soviet Union, with its satellite states, insisted that governments should formulate codes of conduct to ensure 'unbiased and objective reporting', See: See: Giffard, 1989, Nordenstreng, 1984, 79.

${ }^{23}$ Elaborated later as 'Draft Declaration of Fundamental Principles Governing the Use of Mass Media'; UNESCO; COM-74/CONF, 616/3, 23 January 1974: http://unesdoc.unesco.org/images/0001/000104/010440eb.pdf

${ }^{24}$ Eventually attempts to establish the Mass Media Declaration on the role, responsibilities and functions of the media failed. However, the US and the UK withdrew from the UNESCO for a year. See: Giffard, C. A. UNESCO and the media New York: Longman, 1989

25 'Action Program for Economic Co-operation' reprinted in O. Tankowitsch and K. Sauvant, The Third World without Super Powers: the Collected Documents of the non-Aligned Countries; Debs Ferry, N.Y.: Oceana, 1978

${ }^{26}$ The result of the debate was the establishment in 1975 of the Non-Aligned News Agencies Pool, coordinated by the Yugoslav news agency Tanjug with an aim to provide objective information on economic, social and cultural development of the Third World. Some observers considered the new pool as the first direct challenge to the power of the Western news agencies. See: Marks, $1981,29$.

${ }^{27}$ Jonathan Gunter, The United States and the Debate on the World Information Order, Washington: USICA, 1979

${ }^{28}$ Jérôme Bourdon, 'Imperialism, Self-inflicted? On the Americanizations of Television in Europe', in William Uricchio (ed), We Europeans? Media, Representations, Identities, Intellect, 2008

${ }^{29}$ This stands true for the European Community (EC) in the 1980s. Earlier however, cinema and film quotas in particular had been of central importance to some of the EC individual Member States. The agreement on the post war aid and trade that France signed with the United States, known as the Blum-Byrnes Accord, was to aid the French economy, through low interest loans and liquidation of French war debts. France agreed to open its market go US exports and abandon its tariffs and quotas on imports. The one and only exception that the French government made was the film industry; see: Patricia Goff, Limits to liberalization: local culture in a global marketplace, Ithaca: Cornell University Press, 2007
} 
cultural and political integration..$^{30}$ Television was regarded as "more influential and less nationally encumbered medium than print." ${ }^{\prime 1}$ The Directive was at the time envisaged to remedy the plague of most European channels: the 'Americanisation' of content. ${ }^{32}$ The arrival of satellite broadcasting brought the possibility of creating a European audiovisual space through launching a Europe-wide television channel. ${ }^{33}$

The idea to launch a pan-European television channel was born in the EU Parliament in 1980. The Parliament called for the "establishment of a European radio and television company with its own channel." ${ }^{4}$ The channel was to cater for a general public and feature programs in "politics, education, cultural information, entertainment and also advertising". It was to broadcast multilingually to reach the widest possible audience. Soon, the European Commission also called for a programming mix of "news, politics, education, culture, entertainment and sport, in which the European viewpoint would be based on the ideals and realities of the cultural unity of Europe". ${ }^{35}$ The Commission was also ready to financially support such a Europe-wide TV channel. Several concrete initiatives came out of the Parliament's and Commission's initiatives. Two first initiatives, Eurikon TV ${ }^{36}$ and Europa $T V^{37}$, failed after a few years of operation. But it was third time lucky when Euronews was born.

Euronews is the longest running pan-European channel so far. Launched in $1993^{38}$, unlike Eurikon or Europa TV, it does not aspire to deliver general programming to reach a general audience. It limits itself to news and current affairs delivered via cable, digital satellite and terrestrial channels. The broadcaster came into existence at a very peculiar moment in European history. Sergio Cantone, Euronews programming manager at the Brussels office, explains:

When the Desert Storm happened in February 1991, during the first war in Iraq, there was just one single and unique player on a global scale from the news point of view. It was CNN. So, the idea was to create a

30 'Television without Frontiers' Directive of 1989 imposed compulsory content quotas asking broadcasters to reserve "where practicable and by appropriate means" a majority proportion of their air time to European productions and independent European productions excluding time devoted to news, sports, games, advertising, teletext services and teleshopping (Article 4 and 5).

${ }^{31}$ Kevin Williams, European Media Studies, Hodder Education, 2005, 13

${ }^{32}$ Philip Schlesinger, 'Tensions in the construction of European media policies' in: Nancy Morris and Silvio Waisbord (eds.) Media and globalization: why the state matters; Lanham, MD: Rowman \& Littlefield, 2001

${ }^{33}$ The actions and measures undertaken to address the multiple aims occurred in several areas of audiovisual field. The European Community encouraged the creation of pan-national television, passed new pan-European laws for broadcasting sector, offered support programs for cinema and television production (Media Programs), supported public service broadcasters in its Member States in the Treaty of Amsterdam, encouraged international agreements of MS with third (non-EU) countries to enhance European production.

${ }^{34}$ European Parliament, 'Motion for a resolution on radio and television broadcasting in the European Community', EP Doc, No. 1-409, 1980

${ }^{35}$ European Commission, 'Realities and Tendencies in European television: Perspectives and options', Report from the Commission to the European Parliament, COM (1983), 229 final, 1983

${ }^{36}$ Eurikon TV started by fifteen European broadcasters, European Community and European Broadcasting Union in 1982 delivered mainly news, documentaries, sport, entertainment, music, films, religious as well as children's programming (Collins, 1993; Theiler, 1999). Eurikon failed after barely a year of operation due to that fact that audiences found it hard to understand its programming and to relate to it (Collins, 1993). Cultural and linguistic barriers were not overcome as dubbing and subtitling efforts were deemed unsatisfactory: See; Tobias Theiler, "Viewers into Europeans? How the European Union tried to Europeanize the audiovisual sector, and why it failed', Canadian Journal of Communication, Vol. 24,1999 ${ }^{37}$ Europa TV was the second attempt to establish a Europe-wide television channel in 1985. Five public service broadcasters from Germany, Ireland, Italy, the Netherlands and Portugal took part in the project with financial contributions from the Dutch government, the European Commission and advertising. Some major European broadcasters like BBC and French Antenne 2 decided or were convinced by their governments not to participate in the undertaking. Europa aspired to be a pan-national channel, not only with regard to its geographical reach but also its content with the mission to produce programs of non-national format in the first place as well as non-national reporting. Its news team "was carefully structured to avoid the dominance of any single national group" and "non-national perspective was encouraged by all available means", See: Maggiore, M., Audiovisual production in the single market, Luxembourg: Commission of the European Communities; Lanham, MD, 1990, 71. Due to financial difficulties, Europa TV ceased its operations after one year of existence reaching only 4.5 million households across Europe. Theiler, 1999, argues that Europa suffered also from the 'general lack of direction and leadership'. And, like in the case of Eurikon, distribution was scarce, culturally and linguistically fragmented audiences did not find Europa's programming appealing, therefore it could not attract advertising to support its budget; See: Negrine, R. and Papathanassopoulos, S. 'The Internationalization of Television' in European Journal of Communication, Vol. 6, No. 1. SAGE Publications, 1991. Others claim that, 'cultural discount' is to blame for why a "particular program rooted in one culture, and thus attractive in that environment will have a diminished appeal elsewhere as viewers find it difficult to identify with the style, values, beliefs, institutions and behavioural patterns of the material in question"; See: Hoskins, C. and Mirus, R. (1988) 'Reasons for the US dominance of the international trade in television programmes' in: Media, Culture \& Society, Vol. 10, No. 4, 499-504 SAGE Publications, 1988,50

${ }^{38}$ Euronews was an initiative of mostly public broadcasters from across and outside the EU: Belgium, Cyprus, Egypt, Finland, France, Greece, Italy, Monaco, Portugal, and Spain. Based in Lyon, France and distributed via cable and satellite, Euronews broadcasts simultaneously in eleven languages. 
E. Polonska-Kimunguyi and P. Kimunguyi, From European Identity and Media Imperialism to Public Diplomacy

European CNN. It was also a moment when there was a clear direction towards integration in the European Union: Maastricht Treaty was just signed, the Euro and Schengen were in the pipeline, and the Cold War was over, or just over.... So, the decision was taken in '92 and television [Euronews] started in '93. ${ }^{39}$

From its initial broadcast in five languages, the channel has grown to twelve language sections ${ }^{40}$ that employ 370 journalists in Lyon and at the newly opened 'European' office in Brussels. ${ }^{41}$ Despite the early predictions that Europeanisation of political, economic and cultural spheres would not easily be reflected on the television screen, ${ }^{42}$ the channel continues to expand, attracting an audience not only in Europe but also outside. Its worlwide distribution has nearly doubled in the last five years, and currently reaches 333 million households in 153 countries. In Europe, the Middle East and Africa, the channel's main operational areas, Euronews outpaces its competition with regard to households accesssed, and proudly calls itself "Number 1 in Europe." ${ }^{\text {3 }}$

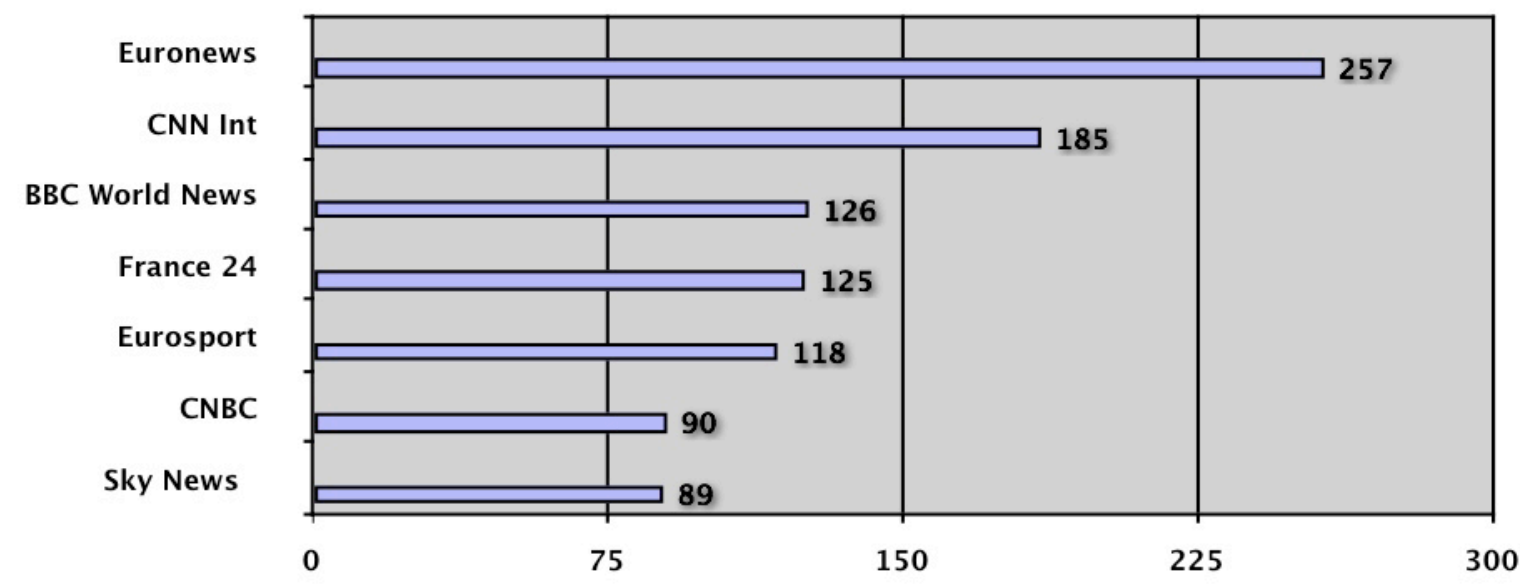

Fig.1. Distribution in Europe, the Middle East and Africa (in millions of households). Source: "Euronews: pure”, 2011

Despite the very high figures in distribution, 2.7 million cable and satellite viewers actually watch the channel every day. Although the figure is much smaller than the potential reach of distribution, it is still higher than that of $C N N$ and $B B C$ World News combined. A further 3.3 million viewers access the channel on a daily basis through its national window broadcasts ${ }^{44}$ Thus, the battle to conquer European hearts and minds against the backdrop of the earlier American domination has proven to be a success story as audiences continue to watch Euronews.

Euronews produces little of its own content. The majority of the channel's programming comes through the Eurovison Exchange, from programming of its twenty one stakeholders - public service broadcasters from Europe, Russia, Middle East and North Africa - as well as from major press and TV news agencies. There is no newscaster, a face that would read the news in each langugage. There is an image sequence accompanied by twelve language stories.

\footnotetext{
${ }^{39}$ Interview with Sergio Cantone, July 2011

${ }^{40}$ Arabic, English, French, German, Italian, Persian, Polish, Portuguese, Russian, Spanish, Turkish, Ukrainian.

${ }^{41}$ The Brussels office is specifically devoted to the coverage of the EU-related events.

${ }^{42}$ Hans-Günther Brüske, "Spiel mit und gegen Grenzen. Profile einer europäischen Fernsehkultur", in Schardt, A. and Brüske, H.G. (eds.) Europa auf dem Bildschrim.Szenarium der europäischen Fernsehwirklichkeit, Bonn, 1986

${ }^{43}$ Euronews ,'Euronews Pure', Euronews Media Pack, 2011, available at: http://www.euronews.com/media/download/mediapack/euronews mediapack en 2011.pdf

${ }^{44}$ Euronews, 2011
} 


\subsection{Between National and European: Seeking its Own Perspective}

The channel does not pretend that it covers events from an undefined or non-existent European point of view. "We are a chorus, not a soloist", maintains Cantone, "we have a cover song that is played and sung by many singers with different music, but the song is the same..." 45 This offical rejection of a vaguely defined European perspective by the channel's management means that Euronews significantly differs from its Eurikon and Europa predecessors and this factor might have contributed to its success. Viewers are well aware of where the program comes from, and thus, the national focus or approach of the story is known. In its own news programs (as opposed to those submitted by stakeholders), the channel allows journalists to adhere to national references, allusions and foci.

The only 'common' or 'European' feature of Euronews, as described by the channel's journalists, is the orientation and regional focus of news. "We are free to cover whatever stories we like, from whatever regions we like", says Fariba Mavaddat, from the Persian section, "but we are supposed to cover stories that are more relevant to the day-to-day life of the Europeans and European governments, the European citizen." 46 This has been true since the beginning of the channel's operation as "even topics which appear to be exclusively national are placed in a transnational context." 47 Thus, the selection of topics is visibly 'European'. Presently around seventy per cent of the news content broadcast by Euronews is Europe-related. During the Summits of the European (EU) heads of states, this figure may even reach eighty per cent. ${ }^{48}$ Sadly, however, the selection of stories and topics would be the only 'European' feature at Euronews. Journalistic cultures, values and approaches are shaped by national practices.

The gatekeepers in Lyon, and recently in Brussels, are not subject to national constraints when selecting and allocating a news item. ${ }^{49}$ Journalists deny that nationally learnt practices come to the fore. ${ }^{50}$ Yet, coming from the many national backgrounds, journalists employed by Euronews may have very different understanding of journalism, its practice and purpose. For example, the existing literature suggests that journalists from the Anglo-Saxon model put more pressure on objectivity and impartiality, while taking sides and open advocacy is commonplace in Mediterranean states. ${ }^{51}$ Eastern Europe and the Arab world, from which Euronews has recently recruited staff for its newest language services, enjoy yet another set of values, not necessarily consistent with that of liberal democratic journalism. ${ }^{52}$

The varied national values find their way to the Euronews stories via the diverse national practices and narratives of the channel's twelve official languages. Journalists from all language sections admit that their job is not to simply translate one text into the twelve stories that accompany the same visual message. ${ }^{53}$ Their job is to write their own accounts. "There is absolutely no text", explains Fariba Mavaddat from the Iranian service, "with a few exceptions, we receive a pool of information from respected news agencies, the editors provide us with a film, and then we do

\footnotetext{
${ }^{45}$ Interview with Sergio Cantone, Euronews, July 2011.

${ }^{46}$ Interview with Galina Polonskaya, Euronews, July 2011

${ }^{47}$ Hans-Peter Siebenhaar, (1994) Europa als audiovisueller Raum. Ordnungspolitik des Grenzuberschreitenden Fernsehens. Opladen: Leske \& Budrich, 1994, 254

${ }^{48}$ Interviews with Sergio Cantone, Galina Polonskaya and Gul Shum Alam, Euronews, July 2011

${ }^{49}$ Marcel Machill, "Euronews: the first European news channel as a case study for media industry development in Europe and for spectra of transnational journalism research", in Media Culture Society, Vol. 20, 1998

${ }^{50}$ Interviews with Sergio Cantone, Galina Polonskaya and Gul Shum Alam, Fariba Mavaddat, Euronews, July 2011

${ }^{51}$ David Hallin and Paolo Mancini, Comparing Media Systems: Three Models of Media and Politics, Cambridge: Cambridge University Press, 2004

${ }^{52}$ Media in Central and Eastern Europe are widely considered to fall within the mediterrenean model. Corruption, political influence, politicisation of public service broadcasters and national broadcasting councils is comonplace in CEE; See: Karol Jakubowicz, Ideas in our heads: Introduction of PSB as part of media system change in Central and Eastern Europe. European Journal of Communication, 19 (1), 2004; Eva Polonska-Kimunguyi, 'Media and Democracy in Central and Eastern Europe; the Promise of 1989 Revisited', refereed proceedings of the Australian and New Zealand Communication Association Conference, Canberra, July 2010. Pintak and Ginges examined Arab newsrooms to provide a snapshot of values and practices used throughout the region. They have found out that the Arab journalism, in the eyes of journalists, is believed to lack independence, fairness and professionalism; Arab journalists believe reporting should be infused with respect and that journalists may also be political activists, but they ultimately aspire to objectivity. See: Lawrence Pintak and Jeremy Ginges, "Inside the Arab Newsroom: Arab journalists evaluate themselves and the competition" in Journalism Studies, Vol. 10, No 2, Routledge, 2009

${ }^{53}$ Interviews with Sergio Cantone, Galina Polonskaya and Gul Shum Alam, Fariba Mavaddat, Euronews, July 2011
} 
our research on our own with access to multiple sources: Persian, Turkish, French... you name it... Once the story is ready, we just voice it over the film." 54 "Everyone treats the story in their own way," adds Galina Polonskaya from the Russian section, "We have the information, we have the main news, the data, the sound bites ... we go to our desks and write the scripts on our own". ${ }^{55}$ What comes out may at times only loosely resemble the same message. Stories vary not only linguistically, but also with regards to the information provided.

Machill conducted a detailed content analysis of the channel's news items by looking at versions of the same story transmitted in five languages at the time of transmission..$^{56} \mathrm{He}$ concluded that there were in fact considerable variations in the design of news items. The German and the English versions 'sold' the developments in the classical lead-in, whilst in the French version the actual report on the events featured only in the second half of the story. This design resulted in the French story containing the lowest informational content, compared with the other formats. The Spanish and the Italian versions offered value judgements, not seen in other texts, before moving on to the key statements. Mitchell's analysis took one story as a sample, thus, his conclusions cannot be extended to the general practice of the various language sections. What he did demonstrate, however, was that whilst the image sequence remained the same for all language formats, it was supplemented by different texts. Journalists admit that this situations holds today. Different amounts of background information are required for different audiences; different treatment of the key actors, events and statements is also apparent. ${ }^{57}$

As national bias influences how news is reported through varying linguistic approaches, they ocassionally influences what is being said by Euronews. At the time of conducting the interviews with journalists at the broadcaster's Brussels office, the Libyan uprising was in full swing. Many attitudes existed in Europe towards the intervention in Libya. States and their publics differed not only with regard to the approach, but to the very question of whether to intervene or not and, if yes, on what grounds. As Cantone, editor in charge of the Brussels office, admits:

The French are in the position they don't want to negotiate with Gadaffi, and the Italians have a position that they do want to negotiate with Gadaffi... actually they are doing it secretely... Of course, the Italian journalist will mention this fact and the French will mention the other fact more... The journalists should always give the information that is of concern to their audience and their language .... But we try to make sure that the Italian section doesn't say that the French are there to get the oil..$^{58}$

Although Cantone maintains that these are just "nuances, not different stories", different approaches to story writing prevail at Euronews. This may mean that not only the linguistic styles vary, but also that national journalistic practices, goals and preferred ways of thinking influence the broadcaster's information output. This is hardly a surprise, as ample evidence exists that professional journalism worldwide has developed in the context of special protection of nation states, ${ }^{59}$ and still remains a "prisoner of the nation-state. ${ }^{" 00}$ The distributed contents and agendas, occupational ideologies and routine practices of journalism have been 'deeply synchronised with apparatuses and identities of nation states. ${ }^{\prime 61}$ Thus, the biggest challenge for Euronews, if it is serious about its declared goals, to "maintain impartiality and avoid a national viewpoint", ${ }^{2}$ is to relinguish these national trappings from the common newsroom and make sure they remain "nuances".

The broadcaster is aware of these shortcomings and makes neutrality of news its official policy. Journalists receive tough supervision from chiefs of each language service, and careful employment policies are also in place to avoid

\footnotetext{
${ }^{54}$ Interview with Galina Polonskaya, Euronews, July 2011

${ }^{55}$ Interview with Gul Shum Alam, Euronews, July 2011

${ }^{56}$ Machill, 1998

${ }^{57}$ Interviews with Sergio Cantone, Galina Polonskaya and Gul Shum Alam, Fariba Mavaddat, Euronews, July 2011

${ }^{58}$ Interview with Sergio Cantone, Euronews, 2011

${ }^{59}$ Brian McNair, Cultural Chaos. London: Routledge, 2006

${ }^{60}$ Ulrich Beck, 'Toward a New Critical Theory with Cosmopolitan Intent', Constellations 10(4), 2003, 454

${ }^{61}$ Heikki Heikkilä, H. and Risto Kunelius, "Ambivalent ambassadors and realistic reporters: The calling of cosmopolitanism and the seduction of the secular in EU journalism”, in Journalism, SAGE Publications, 2008

${ }^{62}$ Euronews, 2011
} 
E. Polonska-Kimunguyi and P. Kimunguyi, From European Identity and Media Imperialism to Public Diplomacy

recruiting political activists. ${ }^{63}$ Program editors emphasise that Euronews is not "part of the great game played by national Foreign Ministers, ... it is not the projection of the French, or the Italian, or the Russian Foreign Minister." ${ }^{44} \mathrm{~A}$ case in point would be another story run throughout the summer of 2011 on the arrest of Dominiq Strauss-Khann: ${ }^{65}$

If you looked at the coverage in the French media, you'd see that the media enter into the polemics related to the elections...there is a passionate political game involved in this story. Media participate in the political competition in order to attack either the Socialists, or the Right, or to open up a discussion in France about politicians and sex as a national problem and a problem of society. We [Euronews] give the facts that Dominiq Strauss-Khann was arrested, that it might affect his political future and the future of France and that's it. We miss all the polemic around it. Even Euronews in its French version doesn't give the impression of political engagement. ${ }^{66}$

Thus, objectivity, balance and impartiality are the values most often highlighted by the broadcaster's staff. "The journalist should give a balanced view of the story, full stop, no arguments about it," says Fariba from the Iranian section. "You never give one side of the story, otherwise you're Fox News." ${ }^{67}$ From this editorial emphasis on staying out of the 'political game', it would seem that Euronews adopts the North - Anglo-Saxon model of journalism, where objectivity remains one of its core foundations.

Avoiding national viewpoints and trying not to achieve a common European perspective is a tricky job. At present, Euronews seems to be suffering from a structural contradiction: its staff are not to express their national views, but the only sources available for their news production are national news agencies that provide footage and texts. Journalists do not tend to stay with the broadcaster long, as the turnover is quite high. There is no prospect of producing a generation of 'Euro-journalists' with common values and styles, as new recruits bring their national qualities as staff change every few years. Thus, writing stories in national languages is bound to convey national values and ways of thinking. Oscillating between the national and the common-European spheres seems to be the broadcaster's permanent identity.

\section{Going GIobal: Communicating Europe to the World}

There has been a recent shift in the rationale behind maintaining Euronews. More recently the broadcaster has been on a global quest for a global audience. This is not new in international broadcasting, as the media have long appealed to governments as an efficient way to reach audiences beyond national borders. ${ }^{68}$ According to Price (2003), international broadcasting is the "elegant term for a complex combination of state-sponsored news, information, and entertainment directed at a population outside the sponsoring state's boundaries." ${ }^{69}$ Early in the 1960s, US President Kennedy sought to build up Voice of America for the 'peaceful revolution' of socialist countries, hoping that broadcasts would "leap the national borders and oceans, the Iron Curtain and stone walls, in a life-and-death competition with communism." 70 The ultimate victory of liberal democracy over communism was largely attributed to international media

\footnotetext{
${ }^{63}$ Interview with Galina Polonskaya, Euronews, 2011

${ }^{64}$ Interview Sergio Cantone, Euronews, 2011

${ }^{65}$ Dominiq Strauss-Khann, the director of International Monetary Fund, and an official candidate in the French presidential elections, was arrested for the alleged sexual harrasment of made in a New York hotel.

${ }^{66}$ Interview Sergio Cantone, Euronews, 2011

${ }^{67}$ Interview with Galina Polonskaya, Euronews, 2011

${ }^{68}$ Eva Polonska-Kimunguyi, 'In Defence of Content Quotas: Regulation of Broadcasting in the European Union' in Media and Arts Law Review, Lexis-Nexis: Butterworths, Vol. 15, No. 3, 2010; Jeremy Tunstall, The Media Were American: U.S. Mass Media in Decline; Oxford University Press, 2010

${ }^{69}$ Monroe Price, "Public Diplomacy and the Transformation of International Broadcasting"; Cardozo Arts and Entertainment Law Journal, Vol. 21, 2003, 53

${ }^{70}$ cited in Price, 2003, 55
} 
and the information efforts of the West. ${ }^{71}$ The Cold War model of international broadcasting, however, repeatedly crossed the thin line between information and propaganda. It assumed an intellectually needy and welcoming audience and was often supported by the display of a military muscle. As such, scholars have argued, it has now become obsolete. ${ }^{72}$

Thus, the initial mission of Euronews - to provide diversity of culture, diversity of religion and diversity of opinion against the backdrop of the single (American) voice in the international arena - is not only valid, but has recently aquired a new purpose: it is now a voice of Europe for the rest of the world. Started by five national broadcasters, and now broadcasting in twelve languages, Euronews is clearly on a global hunt. The establishement of the Portuguese language section in 1999 was accompanied by the channel's take-off in South America, and soon after in North America and Canada. The channel's launch in Asia in 2004 opened the door for broadcasts worldwide. ${ }^{73}$ Russian, Arabic, Turkish, Persian, Polish and Ukrainian languages soon followed, together with the new technologies enabling delivery of the channel's message to areas where traditional broadcasting has no reach. Most of the new developments at Euronews clearly target audiences outside the EU and the European continent. This also coincides with the EU's efforts to establish its common foreign policy. "We're going global because the European Union is going global..." explains Sergio Cantone, editor in charge of the Brussels office.

It's about soft power projection, it's about talking to other people, neighbours of Europe, the Arabic people for example. There are important things happening there at the moment: the Arabic revolutions....We think that there is a growing demand from these countries for support en l'heure de la rigeur from the European countries and from the European Union... But there are also commercial reasons. It's about competition and media competition...for instance we have Al-Jazeera which is broadcasting in English, we have BBC that broadcasts in Arabic, so we should also broadcast in Arabic, we should also broadcast in Persian... ${ }^{74}$

Several of the broadcaster's languages transmit European political values, such as democracy, rule of law, and human rights, ${ }^{75}$ to regions where they are not necessarily desired and upheld by governments. Iran, Turkey, Russia and the Arab world are not declared democracies, yet they all receive Euronews coverage through its liberal lens. How is the 'European story' received in this non-liberal environment? Euronews journalists believe that viewers watching their respective broadcasts respect the channel. "Unlike most international boradcasters in Iran, we're very lucky", says Fariba from the Iranian service.

We are not accepted by the government...it's illegal. But l've seen the picture of Tehran from above. It's like a mushroom field with all the satellite dishes. Everyobdy has one. And the government knows, tolerates it...We [Euronews] have a degree of respect, from the people and from the government itself. ${ }^{76}$

Fariba explains that in Iran, Euronews in the Persian language appeals particularly to the people in the capital "who are very closely associated with European culture [in Iran] before the revolution ... who now long to learn about Europe."

They don't have a positive view of America on the whole because of the mistakes Americans have made over the past twenty years in Somalia, in Sudan, in Iraq, in Afghanistan and now in Libya. They used to welcome Americans back in Iran but now they have their doubts... they don't trust them. With Europeans it's different. They view Europeans as level-headed and sensible although they have their doubts about the intentions of the British and the French governments. On the whole, they think Europeans can handle the situation much more sensibly than the Mullas are doing now, and the Americans will ever do in the future, if at all... ${ }^{77}$

\footnotetext{
${ }^{71}$ Joseph Nye Jr., "Public Diplomacy and Soft Power"; The ANNALS of the American Academy of Political and Social Science, vol. 616,2008

72 Philip Seib, "Public Diplomacy, New Media and Counter-Terrorism', in CPD Papers on Public Diplomacy, USC Center on Public Diplomacy, Paper

2, 2011

${ }^{73}$ Euronews, 2011

${ }^{74}$ Interview with Sergio Cantone, 2011

${ }^{75}$ Interviews with Sergio Cantone, Galina Polonskaya and Gul Shum Alam, Fariba Mavaddat, Euronews, 2011

${ }^{76}$ Interview with Galina Polonskaya, Euronews, 2011

77 Interview with Galina Polonskaya, Euronews, 2011
} 
Euronews and its broadcasts also appeal to the Arabic speaking communities living in Europe. "They like Euronews very much," maintains the editor in chief from Brussels. "They do appreciate that we are part of pluralism in the Arab world... we have our position, we try to be objective and transparent. Our position is less fractious and partisan than that of other media. We're not the voice of Foreign Ministers." 78

The attitude towards Euronews is different in Russia and Turkey whose citizens enjoy relative freedom in access to multiple channels and multiple perspectives. Here Euronews is also considered to be watched by the educated and well-travelled middle class, but may not necessarily always be relevant. ${ }^{79}$ "One of the reasons," explains Gülsüm Alen from the Turkish service, "is that there are no stories about Turkey, there are no Turkish faces on Euronews. If we don't cover Turkey for the Turkish people, we're not credible."80

The recent investments of Euronews clearly indicate the channel's global aspirations. Yet at the same time, the broadcaster ties itself to the European Union by accepting a grant from the EU Commission to increase EU-related coverage. Although the grant itself does not constitue the majority of Euronews revenue, it comes at a time when national politics are responsible and acccountable to the European Union, and national laws and policy-making are no longer exclusively in the hands of national parliaments. ${ }^{81}$ Thus, communicating 'Europe' may now be equivalent to communicating the European Union.

\section{Conclusion}

The emergence of the European Union has presented a challenge to national politics and identities in Europe. As the communicative actions of the EU are dictated by the need for democratic legitimacy, effective dialogue with its own citizens remains the EU's greatest test. ${ }^{82}$ This article has looked at Euronews, Europe's multilingual broadcaster, and its contribution to the new pan-national communication environement. Although the channel did not begin its operations as an EU broadcaster, it is significantly tied to the European Union. This is visible in the financial arrangements it has with the European Union, as well as in its increasing EU-related coverage. The Union also provided significant incentives for the creation of the broadcaster in its early days. The People's Europe innitiative of the 1980s, that placed media industries at the heart of pan-national identity building, resulted in the emergence of new legislative and financial arrangements in the sector.

In the early years of the channel's operation, Euronews' 'stylistic constraints and limited resources have led to a rather characterless journalism, heavily tied to pictures rather than analysis, with little that is characteristically European about its news agenda. ${ }^{83}$ Today, as the article has demonstrated, the channel still struggles to find its own perspective. Euronews, with its trans-national orientation and organisational setting, is caught in-between a vaguely defined European identity and the many national linguistic, cultural and professional contexts that contribute to its output. The tension between the national and European prevails.

Despite the unresolved tensions, Euronews is recently on a path to punch above its weight. From a 'glue' that it once aspired to be, to unite Europeans around common goals and ideals, through to providing an alternative view to the American-dominated global information flow, the broadcaster is now exporting European values beyond the continent.

\footnotetext{
${ }^{78}$ Interview with Sergio Cantone, Euronews, 2011

${ }^{79}$ Interviews with Gul Shum Alam, Fariba Mavaddat, Euronews, 2011

${ }^{80}$ Interview with Fariba Mavaddat, Euronews, 2011

${ }^{81}$ The term "Europeanisation" has entered political discourse in Europe, signifying the political, economic, cultural and institutional changes. It is a result of an unavoidable encounter of the 27 now European states with the supranational level. The European Union, increasingly a center of political economic and legal activities of nation states, is potentially a new supranational form of state. See: Schlesinger, 2001.

${ }^{82}$ Aneta Podkalicka and Chris Shore, 'Communicating Europe? Communication Policy and Cultural Politics', in Valentini, Ch. And Nesti, G. (eds.)

Public Communication in the European Union: History, Perspectives and Challenges, Cambridge Scholars Publishing, 2010

${ }^{83}$ Philip Schlesinger, "Europe's contradictory communicative space", Daedalus Boston, No. 123, Issue 2, 1994,42
} 
E. Polonska-Kimunguyi and P. Kimunguyi, From European Identity and Media Imperialism to Public Diplomacy

Euronews has accepted EU funding to do so, and it 'goes global because the European Union is going global.' ${ }^{84}$ Thus, it may seem that the broadcaster has now officially become an instrument of the EU transnational public diplomacy.

With the new purpose of becoming the EU's ambassador to the global audience, the tensions between European and the varying national perspectives must be resolved. The channel represents a very rare transnationally-minded community of journalists who are deeply aware of the changing context of journalism and could possibly contribute to Europeanisation of the profession and its outcomes. At a time of growing competition in the broadcasting field and the plethora of new players on the global communication arena, the channel's unique position could potentially play a role in the survival and consolidation of the European journalism, its norms and profesional values.

\section{B i o graphy}

Eva Polonska-Kimunguyi obtained her PhD from the University of Melbourne where she studied media and audiovisual policy of the European Union. She received a Master of Arts in Political Science and Journalism from the University of Warsaw, Poland and worked as a journalist for Polish national television. She has lectured in media and contemporary European politics, democracy and global politics and is now a lecturer of European studies at Monash University. She has recently published two books on Culture, Identity and Trade: Regulation of Television Content in the Enlarged European Union (2011) and on Transitions Revisited: Central and Eastern Europe Twenty Years after the Soviet Union (2012).

Patrick Kimunguyi holds a PhD in Political Science and an MA in International Relations from the University of Warsaw. Patrick has lectured in European history and politics at Monash University and in global politics at the University of Melbourne. His current research interests include North-South relations in particular on media perceptions of the EU in Africa. He has published on EU development aid, trade, security, conflict prevention and humanitarian policies.

${ }^{84}$ Interview with Sergio Cantone, Euronews 2011 